\title{
Students' Mathematical Communication Ability through the Brain-Based Learning Approach using Autograph
}

\author{
Mailis Triana ${ }^{1)}$, Cut Morina Zubainur ${ }^{2)}$, Bahrun ${ }^{3)}$ \\ ${ }^{1)}$ Master Student in Mathematics Education, Syiah Kuala University \\ 2) Mathematics Education Department, Syiah Kuala University \\ 3) Early Childhood Education Department, Syiah Kuala University \\ Corresponding author:mailistriana1@.gmail.com
}

\begin{abstract}
Students' skills in expressing mathematical ideas in various ways have not met the expectation. Teachers need to apply the learning providing students' opportunities to present their mathematical ideas. Utilizing the Brain-Based Learning (BBL) approach with Autograph can help students develop their mathematical communication skills. The purpose of this study was to analyze the development of students' mathematical communication skills. Twenty-eight $10^{\text {th }}$ grade students in one of the high schools in Banda Aceh participated in the study. The instruments used were a mathematical communication skills test and the activity observation. Data were analyzed using descriptive analysis. The study showed that mathematics learning applying BBL approach with Autograph contribute to developing students' mathematical communication skills.
\end{abstract}

Keywords: Mathematical Communication Skills, Brain-Based Learning Approach, Autograph

Received: 6" ${ }^{\text {th }}$ October 2018; Revised: 22 ${ }^{\text {nd }}$ January 2019; Accepted: 22 ${ }^{\text {nd }}$ January 2019

\section{Introduction}

Mathematical communication is one of the skills required for students. The skills enable students to understand mathematics through the process of thinking, discussing and decision-making (Viseu \& Oliveira, 2012). The skills can also guide students to demonstrate mathematical ideas in various ways (Utami, 2015). Therefore, mathematical communication skills should be a major concern in mathematics learning to foster students' skills of thinking and conveying ideas.

Mathematical communication skills include the ability to present mathematical ideas verbally, in writing, pictures, graphics and other visual forms (NCTM, 2000). Both verbal and written mathematical communication can strengthen students' understanding of mathematics (Gordah \& Astuti, 2013). The mathematical communication process may also provide students with opportunities to share ideas (Chung, Yoo, Kim, Lee, \& Zeidler, 2016). Therefore, mathematical communication must be well integrated into the classroom and students should be guided to express and write ideas, questions, and 
solutions. Based on some definitions of mathematical communication mentioned before, it can be argued that mathematical communication is the ability to demonstrate mathematical ideas and symbols both verbally and in writing, pictures, or diagrams.

Mathematical communication concerns with the ability to express and justify ideas as well as pose and explain questions (NCTM, 2000). Students' ability to think and convey ideas is strongly influenced by how their brains work as students have different levels of intelligence. Therefore, to optimally stimulate the brain during the learning, a teacher must establish a fun learning environment and challenge students' thinking skills to increase students' engagement leading to more meaningful learning (Jensen, 2008).

Mathematical ideas can be visualized using learning media, one of which is technology (Zayyadi, Supardi, \& Misriyana, 2017). The 2013 curriculum also stipulates that teachers should integrate Information and Computer Technology (ICT) in the classroom (Permendikbud No. 022 Tahun 2016). The use of ICT in mathematics learning can trigger ideas to foster students' thinking skills (Bakar, Ayub, \& Tarmizi, 2010). A learning integrating ICT will motivate students to communicate so that teachers do not dominate the learning process (Sinurat, Syahputra, \& Rajagukguk, 2015).

Students' mathematical communication skills are lacking, far from expected. Students do not have enough opportunities to express their opinions; consequently, students' skills cannot be easily observed leading to students easily quit (Hutagoal, 2013). Also, high school mathematics teachers tend to insufficiently utilize ICT in the mathematics learning process (Rasyidah \& Marzal, 2015). Thus, students have difficulties in developing their communication skills resulting in a lack of students' mathematical communication (Astuti \& Leonard, 2015).

Teachers require to cultivate students' mathematical communication skills through learning providing students opportunities to present their ideas. The learning should also be supported by the use of ICT. Such learning can be achieved using the Brain-Based Learning (BBL) approach with Autograph.

Learning employing the BBL approach can contribute to students' mathematical communication skills (Sukoco, 2016). The BBL guide students to learn meaningfully (Gozuyesil \& Dikici, 2014). The BBL is defined as student-centered learning optimizing students' thinking skills and recognizing that all students have varied ways of learning (Duman, 2006). These ways of learning are elaborated as students not only learn based on the different potential learning styles but also different potential intelligence. Students are given the opportunity to think based on their ways so that students assume that the information can be expressed in open learning (Degen, 2014).

The implementation of the BBL approach in the classroom should consider the following components, namely orchestrated immersion, relaxed alertness, and activate processing. Orchestrated immersion is described as a situation in which students can create patterns and think in their ways when they face problems so that the concepts will be in the students' long-term memory. The learning activities conducted should facilitate students' thinking skills to build their knowledge (Hasliza \& Wan Emilin, 2012).

Relaxed alertness is creating a pleasant circumstance when students are provided with a challenge. Students are required to correctly solve a problem in a comfortable 
situation and not being bored. Activation processing is undertaken by providing learning facilities enabling students to properly absorb the information, for example: forming groups for discussion (Ozden \& Gultekin, 2008).

Autograph is one of mathematical software facilitating students' thinking skills by visualizing mathematical ideas in pictures or graphics. Autograph is a helpful educational tool for teachers and students; it can help teachers to easily present the content materials for the entire class and students understand more because of their visual demonstrations (Bakar, Ayub, \& Tarmizi, 2010). Learning utilizing Autograph allows students opportunities to explore, investigate and discover. In other words, the interaction with the Autograph features may direct students to learning mathematics by exploring so that students can find their solution (Saragih \& Afriati, 2012). Therefore, Autograph is an appropriate software to visualize and understand mathematics. Autographs will be well integrated if the learning process is designed using an approach to meet students' needs.

Several studies related to the mathematical communication (Viseu, 2012; Utami, 2015; Chung, 2016; Muhammad, 2017; Syarifah, 2017), the influence of the BBL approach on the mathematical communication (Sukoco, 2016); and the improvement of mathematical communication through Autograph (Astuti \& Leonard, 2015) have been conducted. However, there have been no studies applying the BBL approach using Autograph. Therefore, the research problem of this study is "to what extent students' mathematical communication skills developed after the learning employing the BBL approach with Autograph?

\section{Research Methods}

This is descriptive research. The subjects of this study were 28 grade 10 students students in one of the high schools in Banda Aceh. They were selected as the subject of the study considering that the topics of the exponent and logarithmic functions were part of $10^{\text {th }}$ grade curriculum. The selection of the school was based on the needs analysis reporting that the learning facilities in the school, such as the availability of a computer laboratory and students being used to a Laptop, were sufficient to conduct the learning using Autograph. The learning facilities in schools are crucial to support the learning process (Sanjaya, 2010).

The instruments used in this study were obtained from the authors' development research and validated by four validators consisting of the learning instrument design experts, the ICT experts, the mathematics teachers often using ICT in the classroom, and peers completed the ICT-based development research. The average validation results of the first, second, third and fourth validators were 3.8, 4.1, 4.2, and 4 respectively. The total average of the validation results was 4.1 indicating that they are highly valid.

Data on the development of students' mathematical communication skills were obtained from the mathematical communication skills test (MCST). MCST consisted of formative tests administered at the end of each lesson and a post-test administered at the end of the learning process. The formative test consisted of one item aiming to examine the development trend of students' score related to the material learned in each lesson, while posttest consisted of three items meeting the indicators of mathematical communication skills. 
Data of formative tests were analyzed descriptively based on the scoring guidelines. The posttest data were analyzed based on the rubrics satisfying the indicators namely: (1) using terms, mathematical symbols, and their structures to model a mathematical problem, (2) expressing mathematical ideas orally, in writing and in a visual description, and (3) interpreting and evaluating the visual mathematical ideas both orally and in writing. The criteria for each indicator was 4 (very good), 3 (good), 2 (adequate), 1 (inadequate) or 0 (highly inadequate). The mathematical communication skills was indicated as being developed if there was a developmental trend of the average formative test scores of each lesson, the results of students' posttest in the good category (indicating by at least $80 \%$ of students were in the good and very good category)

\section{Results and Discussion}

The MCST results were obtained from the formative test and posttest. The analysis showed that the average scores of the first, second, third, fourth and fifth formative tests were $81.03,85.20,86.77,88.60$, and 90.93 respectively. These results indicated that that students' mathematical communication skills in mathematics learning were developing well. However, the average score of the second and the third lesson was only slightly improved. Students were not used to creating mathematical models from real problems by determining the right calculation pattern. This situation leads to the teacher to try to provide students with more opportunities to train the thinking process and explore various ideas at the next lesson. This effort was undertaken to help students to be able to solve problems correctly so that their skills keep developing for the next lessons. Thus, it can be indicated that students' mathematical communication skills are developing in each lesson.

The MCST was also conducted at the end of the learning process consisting of three items in line with the established indicators. The analysis results of MCST posttest is presented in Table 1.

Table 1. The Postest Results

\begin{tabular}{|c|c|c|c|c|c|c|c|}
\hline \multirow[b]{2}{*}{ Item } & \multirow[b]{2}{*}{ Indicators } & \multirow[b]{2}{*}{$\begin{array}{l}\text { Aspect being } \\
\text { observed }\end{array}$} & \multicolumn{5}{|c|}{ Criteria } \\
\hline & & & $\begin{array}{l}\text { Very } \\
\text { good } \\
(4)\end{array}$ & $\begin{array}{c}\text { Good } \\
\text { (3) }\end{array}$ & $\begin{array}{l}\text { Adequate } \\
\text { (2) }\end{array}$ & $\begin{array}{l}\text { Inadequate } \\
\text { (1) }\end{array}$ & $\begin{array}{c}\text { Highly } \\
\text { inadequate } \\
(0)\end{array}$ \\
\hline \multirow{2}{*}{$1 \mathrm{a}$} & \multirow{4}{*}{$\begin{array}{l}\text { Identifying an } \\
\text { exponential function of } \\
\text { a contextual problem } \\
\text { and creating the } \\
\text { mathematical model }\end{array}$} & \multirow{4}{*}{$\begin{array}{l}\text { Writing the } \\
\text { pattern and } \\
\text { relationship the } \\
\text { contextual } \\
\text { problem and the } \\
\text { logarithm } \\
\text { function model }\end{array}$} & 9 & 16 & 3 & 0 & 0 \\
\hline & & & $32 \%$ & $57 \%$ & $11 \%$ & $0 \%$ & $0 \%$ \\
\hline \multirow[t]{2}{*}{$1 \mathrm{~b}$} & & & 8 & 15 & 4 & 1 & 0 \\
\hline & & & $29 \%$ & $54 \%$ & $14 \%$ & $4 \%$ & $0 \%$ \\
\hline \multirow[b]{2}{*}{2} & \multirow{2}{*}{$\begin{array}{l}\text { Expressing } \\
\text { mathematical ideas } \\
\text { in writing and } \\
\text { visualizing them. }\end{array}$} & \multirow{2}{*}{$\begin{array}{l}\text { Drawing a graph } \\
\text { of the logarithm } \\
\text { function and } \\
\text { determining its } \\
\text { characteristics }\end{array}$} & 6 & 18 & 3 & 2 & 0 \\
\hline & & & $21 \%$ & $64 \%$ & $7 \%$ & $7 \%$ & $0 \%$ \\
\hline \multirow[b]{2}{*}{3} & \multirow{2}{*}{$\begin{array}{l}\text { Interpreting and } \\
\text { evaluating visual } \\
\text { mathematical ideas } \\
\text { both orally and in } \\
\text { writing }\end{array}$} & \multirow{2}{*}{$\begin{array}{l}\text { Determining the } \\
\text { equation of the } \\
\text { exponential } \\
\text { function graph } \\
\text { and writing its }\end{array}$} & 7 & 16 & 3 & 2 & 0 \\
\hline & & & $25 \%$ & $57 \%$ & $11 \%$ & $7 \%$ & $0 \%$ \\
\hline
\end{tabular}




\begin{tabular}{|c|c|c|c|c|c|c|c|}
\hline \multirow[b]{2}{*}{ Item } & \multirow[b]{2}{*}{ Indicators } & \multirow[b]{2}{*}{$\begin{array}{c}\text { Aspect being } \\
\text { observed }\end{array}$} & \multicolumn{5}{|c|}{ Criteria } \\
\hline & & & $\begin{array}{l}\text { Very } \\
\text { good } \\
(4)\end{array}$ & $\begin{array}{l}\text { Good } \\
\text { (3) }\end{array}$ & $\begin{array}{l}\text { Adequate } \\
\text { (2) }\end{array}$ & $\begin{array}{l}\text { Inadequate } \\
\text { (1) }\end{array}$ & $\begin{array}{c}\text { Highly } \\
\text { inadequate } \\
(0)\end{array}$ \\
\hline
\end{tabular}

Table 1 shows that the results of the mathematical communication test, for the first indicator of the ability to identify an exponential function of a contextual problem and determine the mathematical model, $86 \%$ of students provided good and very good answers. This means that students provide well-presented, easy to understand and complete solution. Figure 1 below is an example of students' answer of the first indicator for the problem of "A substance injected into the human body will be removed from the blood through the kidneys. Every one hour, kidneys release half of the substance. If 200 mg substance is injected into the human body, how long does it take for the kidneys to release it resulting in the remaining substance of $12.5 \mathrm{mg}$ and what is the logarithmic function model? ". One of the students' answer is presented in Figure 1.

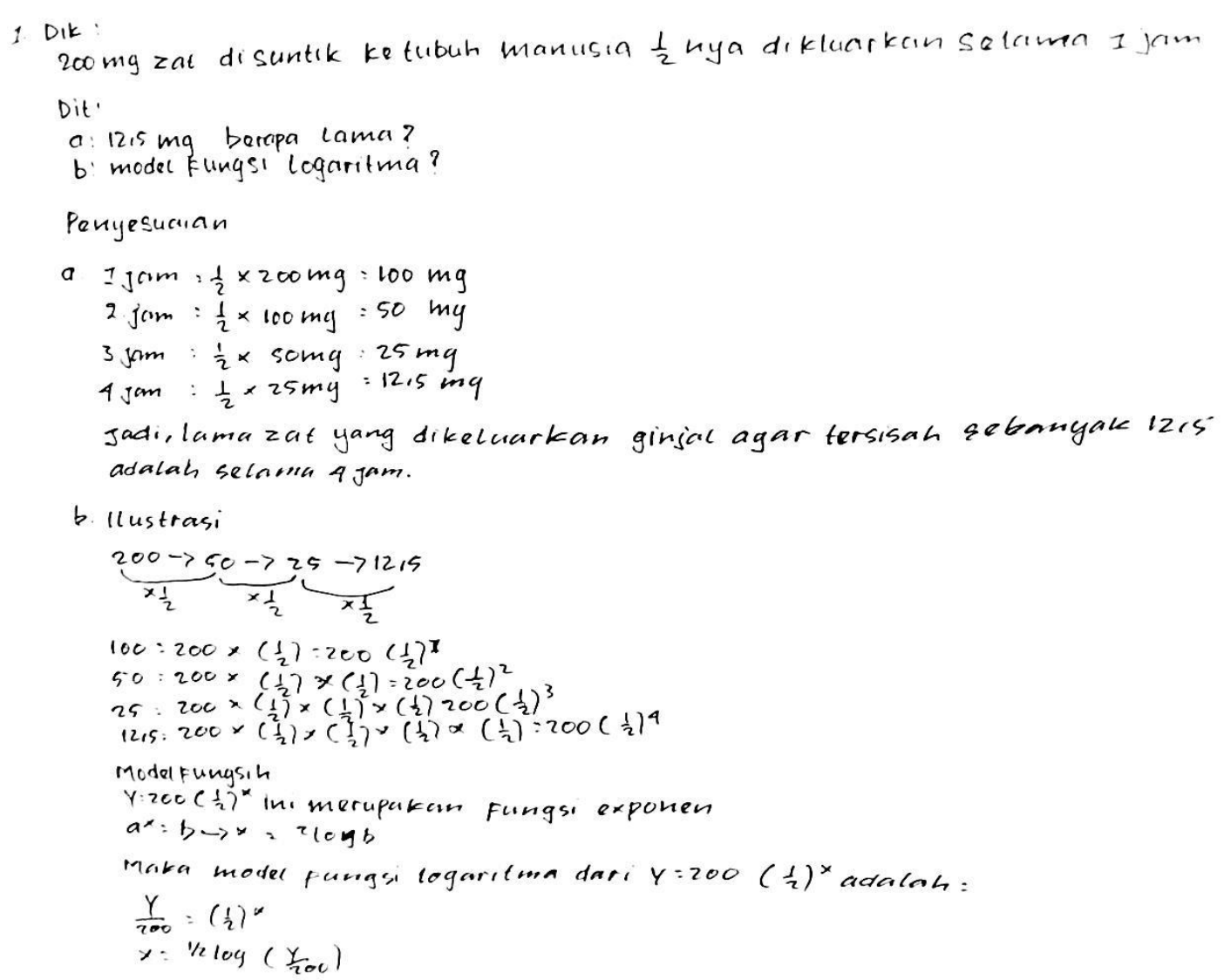

Figure 1. Student answer satisfying the very good criteria for the first indicator

For the second indicator, the ability to express mathematical ideas both in writing and visualize them, $85 \%$ of students provided the good and very good answers. This means that students were able to draw graphs of the exponential and logarithmic functions and correctly express the matters related to the graph such as the influence of the constant value of the function. Figure 2 is an example of the student's answer for 
the second indicator with the problem of "Sketch the graph of function $y=3 \log \mathrm{x}-2$ ! Then write what you know about the influence of the constant value on the graph!”.

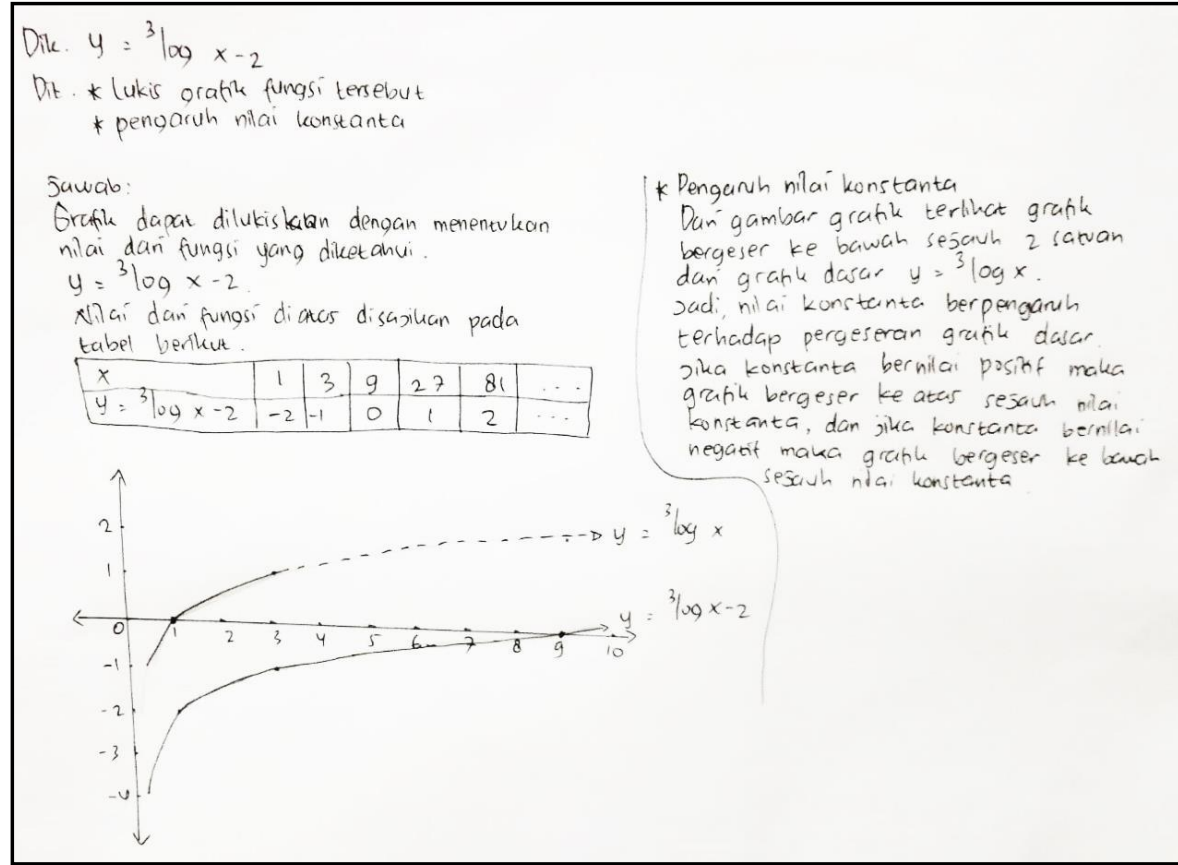

Figure 2. Student answer satisfying the very good criteria for the second indicator

For the third indicator, the ability to interpret and evaluate visual mathematical ideas both orally and in writing, $82 \%$ of students presented the good and very good answers, indicating that students were able to understand the characteristics of an exponential function graph so that they can determine the equation of the function. Figure 4 presents an example of the student's answer to the third indicator with the problem of "note the graph of the exponential function below:

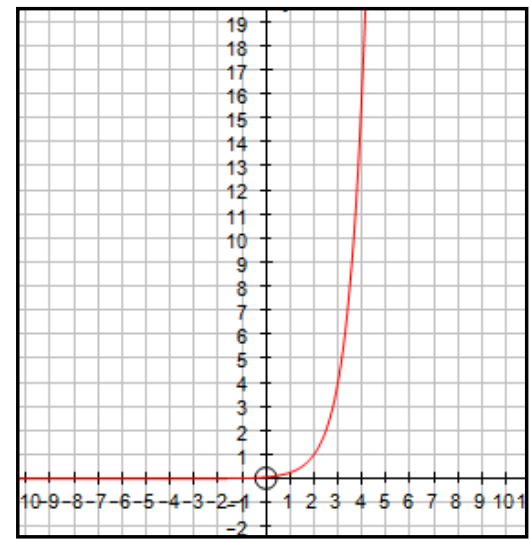

Figure 3. The problem measuring the third indicator

Based on Figure 3, explain the graph characteristics and determine the equation!”. One of the students' answers is presented in Figure 4. 


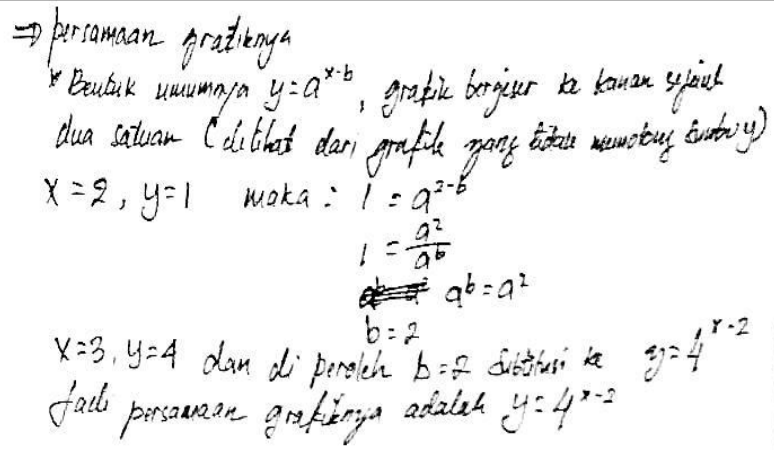

Figure 4. Student's answer satisfying the good criteria of the third indicator

Figure 4 shows that students were able to present the characteristics of the graph provided leading to them writing the equation of the function correctly. The score for the students' answers was at level 3 (good) because students did not provide the complete characteristics of the graph. Students did not mention the characteristics of the graph being monotonously up.

The results showed that some students incorrectly created the mathematical models. One of the reasons is that students were having difficulties expressing mathematical ideas in writing, they found it easier to communicate orally. One of the students' answers presented in Figure 5.

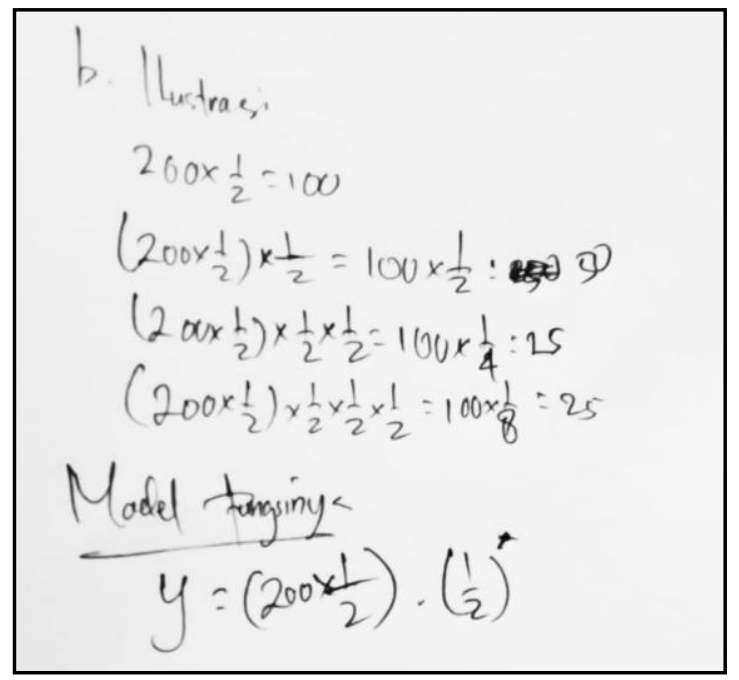

Figure 5. Student's answer not satisfying the good criteria of the first indicator

The student's answer indicated that the correct way of solving the problem, however, she/he incorrectly model the functions. This result is following the research conducted by Syarifah (2017) stating that students' ability to present problems in mathematical models and writing is in the medium category. Students can illustrate the answers, yet they miswrite the mathematical model.

The tendency of the development of good student communication skills is caused by the curiosity of students in learning the Function of Exponents and Logarithms especially by utilizing technology namely Autograph software and influenced by the BBL approach. This is in accordance with the results of the research by Syarwan (2014) which shows that students are very enthusiastic and active during the learning process 
using the BBL approach. Students help each other to understand the material given during group discussions. Students are more accustomed to expressing their ideas or ideas because they are supported by learning conditions that allow the brain to absorb learning to the fullest. The results of the Sukoco study (2016) also showed that mathematics learning using the BBL approach greatly influenced students' mathematical communication skills. In addition, Duman (2006) states that learning with the BBL approach not only develops academic abilities but also provides good motivation for students and teachers with a conducive classroom atmosphere of interest.

Students' ability to communicate well corresponds to the use of ICT. It can help teachers to develop students' abilities to understand, increase the interest, and improve mathematical skills (NCTM, 2008). The learning using technology takes into account each process and connects the graphic representations, algebra, and numerics (Camacho, Depool, \& Santos-Trigo, 2004). The results of Sanapiah's research (2015) showed that visualization of images or graphics could develop students' understanding leading to students being able to communicate their learning outcomes appropriately.

Good students' communication towards mathematics learning is also influenced by the activities of students who can freely explore various charts. This is in line with the Autograph function which can be used to explore multiple graphs in a short time. Saragih (2012) found that graphics drawing using Autograph is clearer than the manual one and it is not time-consuming. Muhammad (2017) also reported that mathematics learning using Autograph software could develop mathematical communication skills.

The use of Autograph in mathematics learning is highly beneficial for the process of achieving the learning goals and for students in drawing the graphs of functions, analyzing and determining the equation of the graph. Also, students can visualize various graphs so that they can interpret the characteristics of the graph, one of the learning objectives. This is in accordance with Hasibuan (2016) argued that Autograph could guide students to identify the relationship between visual and symbolic representations. The analysis results of students' mathematical communication skills during the learning indicate that that students' mathematical communication skills are developing in each lesson.

\section{Conclusion}

Mathematics learning employing the BBL approach with Autograph can develop students' mathematical communication skills. Students' mathematical skills will develop further if teachers use a learning media and select the appropriate strategy to develop and use the learning instrument in teaching mathematics in the classroom.

\section{References}

Astuti, A., \& Leonard, L. (2015). Peran Kemampuan Komunikasi Matematika Terhadap Prestasi Belajar Matematika Siswa. Formatif: Jurnal Ilmiah Pendidikan MIPA, 2(2), 102-110.

Bakar, K. A., Ayub, A. F. M., \& Tarmizi, R. A. (2010). Utilization of computer technology in learning transformation. International Journal of Education and Information Technologies, 4(2), 91-99.

Camacho, M., Depool, R., \& Santos-Trigo, L. M. (2004). Promoting Students Comprehension of Definite Integral and Area Concepts Through the Use of Derive Software. Proceedings of the 26 PME-NA, 2,447-454.

Chung, Y., Yoo, J., Kim, S.-W., Lee, H., \& Zeidler, D. L. (2016). Enhancing students' communication skills in the science classroom through socioscientific issues. International Journal of Science and Mathematics Education, 14(1), 1-27. 
Degen, R. (2014). Brain-Based Learning: The neurological findings about the human brain that every teacher should know to be effective. Amity Global Business Review, 9, 15-23.

Duman, B. (2006). The Effect of Brain-Based Instruction to Improve on Students, Academia Achievement in Social students Instruction. $9^{\text {yh }}$ Internationa Conference on Engineering Education, 24(1),17-25.

Gordah, E. K., \& Astuti, R. (2013). Meningkatkan Kemampuan Komunikasi Matematis Mahasiswa Melalui Pengembangan Bahan Ajar Geometri Dasar Berbasis Model Reciprocal Teaching di STKIP PGRI Pontianak. In Makalah disajikan pada Seminar Nasional Matematika dan Pendidikan Matematika, Universitas Negeri Yogyakarta, 9(2), 227-232.

Gozuyesil, E., \& Dikici, A. (2014). The Effect of Brain-Based Learning on Academic Achievement: A Meta-Analytical Study. Educational Sciences: Theory and Practice, 14(2), 642-648.

Hasibuan, N. H. (2016), Pemanfaatan Autograph sebagai Media Pembelajaran Matematika dengan Menerapkan Model Pembelajaran Berbasis Masalah. Cahaya Pendidikan. 2(1), 34-46.

Hasliza, A., Emilin, W. (2012). New Way to Learn, New Way to Succes: Transforming a Brain-Based Library Via Active Learning Instructions. Proceeding of the IATUL Conferences.

Hutagaol, K. (2013). Pembelajaran kontekstual untuk meningkatkan kemampuan representasi matematis siswa sekolah menengah pertama. Infinity Journal, 2(1), 8599.

Jensen, E. (2008). Brain-Based Learning: Pembelajaran Berbasis Kemampuan Otak. (Terjemahan Narulita Yusron). Yogyakarta: Pustaka Belajar.

Muhammad, I., Nufus, H., Mursalin (2017). Penigkatan Kemampuan Komunikasi Matematika Melalui Pembelajaran Kooperatif Tipe STAD Berabsis IC. Jurnal Kajian Pembelajaran Matematika. 1(2), 113-118.

NCTM. (2000). Principle and standards for School Mathematics. USA: NCTM.Inc.

NCTM. (2008). Principles and Standards for School Mathematics. Virginia: NCTM.

Ozden, M., \& Gultekin. (2008). The Effect to Brain-Based Learning on The Academic Achievement and Retention of Knowledge in Science. Electronic Journal of Science Education. 12(1), 2-9.

Permendikbud No. 022. (2016). Standar Proses Pendidikan Dasar dan Menengah. Jakarta: Menteri Pendidikan dan Kebudayaan Republik Indonesia.

Rasyidah, A., Marzal, J., \& Damris, M. (2015). Investigasi Pengetahuan, Keterampilan dan Implementasi Teknologi Informasi dan Komunikasi (TIK) Guru Matematika SMA/MA Di Kabupaten Tanjung Jabung Barat. Edu-Sains, 4(2), 3745.

Sanapiah. (2015). Peran Penggunaan Ilustrasi Visual dalam Meningkatkan Kemampuan Pemecahan Masalah Matematika Siswa SMP. Jurnal Kependidikan, 14(3), 265-274

Sanjaya, W. (2010). Kurikulum dan Pembelajaran. Jakarta: Kencana.

Saragih, S., \& Afriati, V. (2012). Peningkatan Pemahaman Konsep Grafik Fungsi Trigonometri Siswa SMK melalui Penemuan Terbimbing Berbantuan Software Autograph. Jurnal Pendidikan Matematika, 18(4), 367-381.

Sinurat, M., Syahputra, E., \& Rajagukguk, W. (2015). Pengembangan Media Pembelajaran Matematika Berbantuan Program Flash untuk Meningkatkan Kemampuan Matematik Siswa SMP. Jurnal Tabularasa PPS Unimed, 12(2), 154170. 
Sukoco, H., \& Mahmudi, A. (2016). Pengaruh Pendekatan Brain-Based Learning terhadap Kemampuan Komunikasi Matematis dan Self-Efficacy Siswa SMA. Journal Pythagoras, 11(1), 11-24

Syarifah, T. J., Ponco, S., Rubono, S., (2017). Analisis Kemampuan Komunikasi Matematis Tertulis Ditinjau Dari Gaya Belajar Pada Siswa Kelas 9oXI MIPA 1 SMA Batik 1 Surakarta Tahun Pelajaran 2015/2016. JPMM, 1(2), 1-19.

Syarwan, R., Mukhni., Murni, D. (2014). Pengaruh Pendekatan Brain Based Learning(BBL) terhadap Kemampuan Penalaran Matematis Siswa Kelas VII SMP Islam Raudhatul Jannah Payakumbuh. Jurnal Pendidikan Matematika, 3(1), 29-34.

Utami, C. (2015). Pembelajaran Model Generatif dengan Strategi Group Investigation untuk Meningkatkan Kemampuan Komunikasi Matematis Siswa. Unnes Journal of Mathematics Education Research, 4(1), 18-25.

Viseu, F., \& Oliveira, I. B. (2012). Open-ended tasks in the promotion of classroom communication in Mathematics. International Electronic Journal of Elementary Education, 4(2), 287-300.

Zayyadi, M., Supardi, L., \& Misriyana, S. (2017). Pemanfaatan Teknologi Komputer sebagai Media Pembelajaran pada Guru Matematika. JPMB Jurnal Pengabdian Masyarakat Borneo), 1(2), 25-30. 